\title{
3D COMPUTER ANIMATION: A NEW APPROACH OF RE-DIRECTING STUDENTS INTEREST IN THE STUDY OF AUTOMOBILE TRADE IN THIS $21^{\text {ST }}$ CENTURY
}

\author{
OHWOJERO CHAMBERLAIN
}

Institution- Delta State University, Abraka Delta State Nigeria

\begin{abstract}
Automobile technology in the recent time has contributed immensely to the economic growth of many developed nations. Lack of interest among students in this $21^{\text {st }}$ century in the study of automobile trade has become a global challenge to many nations. This militating problem prompted this research of using $3 D$ computer animation technology to teach 250 students in secondary schools and technical college under apprenticeship training programmed. Quasi-experimental design and intact group was used to carry out the study, using 250 students of boys and girls as control group A, and 250 students of boys and girls for the experimental group $B$ that was taught using $3 D$ animation. The instrument for data collection in the study was questionnaire. The instrument was administered to the students in their different school and place of training. Data collected were analyzed using ANOVA to check for level of significance at 0.05. Findings were observed and recommendations were made based on the findings.
\end{abstract}

KEYWORDS: 3D Computer Animation, Automobile Trade, Lecture Teaching Methods

Received: Aug 24, 2020; Accepted: Sep 14, 2020; Published: Nov 11, 2020; Paper Id.: IJESROCT20203

\section{INTRODUCTION}

The use of $3 \mathrm{D}$ computer animation in this $21^{\text {st }}$ century has brought learning to the door step of people by making learning to be interesting and understanding. Animation can be used as a delivery media where learning can be conducted in a visual state (Anglin, 1996). Animation refers to computerized simulation by processes using image to form a synthetic motional picture. It is a process of putting still images together in a sequence or manner they will appear one after the other creating an illusion movement. (Zahra, 2016). Animation helps learners to visualize a dynamic process which otherwise may be difficult to visualize. 3D animation technique are employed to attain a level of sophistication through which a strong message and lesson on education can be portrayed Cakiroshu \& Yihnaz (2017) state that 3D animation can facilitate learning with 3D objects and allow students to investigate animation videos in event object or concepts more accurately.

Many studies have shown that every student can gain knowledge and understanding from a multimedia based simulated environment (Bhalti et al., 2017). Also, the study aims at the use of multimedia learning approach to develop an animated video to show case a message that would be easily understood by the ordinary student. Kehoe, (1996) review some studies in an animation in education visual aids are found to have a positive effect on learning if certain conditions are met like sensitive tests, explanative test, explanative illustrations, and inexperienced learners (Mayes, 1986). Hendajauni et al. (2018) observed that it is difficult for elementary school student to comprehend what is taught to them in school. He argued that students are changed in the many subjects in school that make many of them to be boring to them. Some uninteresting presentations on the textbooks we have do not help much. The lessons are considered uninteresting to some students because the materials only consist of 
theories or images that do not make students understand the concept in a material. Papstergiou, (2005) examined the high school students' conceptual understanding about the interest and concluded that students experience as users influence to their mental model. It has been discussed and proven by many researchers that animation can encourage and enhance the ability of the learner and viewer to understand and gain the message. Similarly, Xiao, (2013) pointed out that using animations can support learning through the use of new software and hardware techniques.

\section{The Teaching of Automobile with 3d Animation}

The teaching of automobile in the school system to students without practical illustrations has made teaching and learning of automobile to be abstract in nature. In the lecture method of teaching technique, students are made to be silent, and listener to be able to assimilate, the teacher does the teaching and student listens to the teacher is now absolute. It has been observed that learning is an active process that concern and deals with filtering selection organizing and integrating information (Mayer, 2014). There is substantial confirmation that creating visual spatial structure to improve people's ability to recall and understanding brings about effective learning (Mayer, 2001). According to Bellezza, (1986), he stated that learners recalled more words when they are presented with visual presentation like $3 \mathrm{D}$ animation because the visuals are encoded as an intact image in memory before they are retrieved in fact as response to new words.

Spatial construction makes it easier for people to organize the visual representation meaningfully (Wian et al., 1991). Animation is an important component in designing interactive multimedia which creates a visual interest and make scientific learning more appealing and enjoyable for learners (Lith-John Chan Lin, 2000). Animated visual explain the visual and spatial information when these two components are used effectively. The field of computer animation is interdisciplinary and attracts those working in the science and arts applying animation techniques to teach students that will bring understanding (Wiley, 2020). The graphic have played an important role in scientific textbooks for centuries (Brooks et al., 2001). The knowledge of graphics has been used to stimulate interest of students and increase their involvement for instructional purpose.

There has been a considerable amount of research on the process of knowledge acquisition by means of text band graphic. Graphic are sources of visual communication and deliver the textural message effectively (Levie \& Lentz, 1982). The use of graphic helps the teacher to capture the attention of the learner by arranging the components spatially and they thereby use particular capacities of human visual system for perception of spatial configurations (Schools, 1973). Bhatti, (2017) stated that generally multimedia learning involves images and videos along with text, still 3D animation technique are employed to attain a level of sophistication through which a strong message and lesson on education can be portrayed. Various studies show that every student can gain knowledge and understand from a multimedia based simulated environment. The teaching of automobile to the student using 3D animation will help to arouse students' interest and perception of studying automobile technology in the $21^{\text {st }}$ century.

Also, animation is considered a means of supporting to organized the knowledge in the memory and facilitate to recognize the schemes (Liu et al., 2010).

\section{Statement of Problem}

In the recent times, it has been observed that in the African continent, automobile trade is taught to students using lecture methods, which has led to lack of interest in students regarding the learning of automobile trade. On few occasions, they are taught practical. The period they spend on practical is less than three hours in most schools in a week, while they spend 
up to seven or more hours in a week for learning theory. In most cases students are not allowed to work on their own to be acquainted with the practical skill to make learning to be real. The use of 3D animation in the teaching of students will expose the students to practical and theory by seen them and learning, making students to learn visual and theory method, thereby making learning to be real. The purpose of this research is to redirect the teaching of automobile by using the $3 \mathrm{D}$ animation in the $21^{\text {st }}$ century. Munataz (200) interviewed a sample of primary school students and found that children who have experience of ICT at home as well as at the school have a better understanding of the computer system and its functions.

\section{Research Questions}

One research question was developed to carry out the study:

1. The use of 3D animation to teach students will increase students' motivation.

\section{Hypothesis of the Study}

One null hypothesis was formulated and tested at 0.05 level of significant to guide the study:

H0: 3D animation teaching method has no significant difference with students' motivation.

\section{METHODOLOGY}

\section{Research Design}

Quasi-experimental design was used in this study, because intact class group was used to carry out this study.

\section{Population of the Study}

Students who are in their final year and other classes are used for this study.

\section{Sample and Sampling Techniques}

A sample size of 250 students was used as the sample size of the study. Students were selected from the five schools and were taught for five weeks in their various schools after pre-testing using 3D computer animation, before carrying out the post-test for another two weeks.

\section{Instrument}

The instrument used for the research was questionnaire. The instrument consists of two sections. Section A that contains demographic information of the student. Section B contains 12 items that the student will respond to. The questionnaire was designed using the Likert scale. The instrument was validated by three experts from the department of Measurement and Evaluation, and Department of Technical Education unit of University of Nigeria Nsukka, who gave the instrument face and content validity for criticism to give a good construction using a person product moment correlation reliability text that gave the instrument a validation of 0.76 to show that the reliability of the instrument was high making all the items in the instrument reliable.

\section{Data Analysis}

Questionnaire was administered to the students in their various schools in Delta State through the effort of their subject teachers together with the researcher. After administering of the instrument, they were retrieved from the students to give a 
pre-test of the study. Then after one week, they were taught with 3D computer animation to post-test them, the students were highly motivated. After the teaching of the students with the 3D computer animation packages, when post-testing the students responded to the item efficiently. Data collected from each school are as follows. ANOVA was used to analyze the data as stated below:

\section{Federal Government College, Warri}

\begin{tabular}{|c|c|c|c|c|}
\hline & \multicolumn{2}{|c|}{ Control Group } & \multicolumn{2}{c|}{ Experimental Group } \\
\hline & Pre-test & Post-test & Pre-test & Post-test \\
\hline 1 & 10 & 21 & 15 & 39 \\
\hline 2 & 17 & 14 & 10 & 40 \\
\hline 3 & 18 & 22 & 20 & 44 \\
\hline 4 & 19 & 15 & 10 & 43 \\
\hline 5 & 14 & 25 & 16 & 30 \\
\hline 6 & 13 & 26 & 17 & 45 \\
\hline 7 & 16 & 26 & 18 & 33 \\
\hline 8 & 17 & 25 & 19 & 30 \\
\hline 9 & 16 & 21 & 20 & 34 \\
\hline 10 & 20 & 22 & 6 & 45 \\
\hline 11 & 14 & 22 & 15 & 46 \\
\hline 12 & 15 & 22 & 15 & 50 \\
\hline 13 & 16 & 15 & 17 & 47 \\
\hline 14 & 17 & 15 & 14 & 32 \\
\hline 15 & 10 & 15 & 13 & 34 \\
\hline 16 & 12 & 16 & 14 & 27 \\
\hline 17 & 11 & 19 & 15 & 47 \\
\hline 18 & 12 & 17 & 10 & 48 \\
\hline 19 & 13 & 20 & 12 & 49 \\
\hline 20 & 15 & 20 & 15 & 50 \\
\hline
\end{tabular}

Delta State University Secondary School, Abraka

\begin{tabular}{|c|c|c|c|c|}
\hline & \multicolumn{2}{|c|}{ Control Group } & \multicolumn{2}{c|}{ Experimental Group } \\
\hline & Pre-test & Post-test & Pre-test & Post-test \\
\hline 1 & 11 & 20 & 14 & 40 \\
\hline 2 & 13 & 15 & 13 & 38 \\
\hline 3 & 12 & 26 & 15 & 49 \\
\hline 4 & 15 & 22 & 17 & 47 \\
\hline 5 & 6 & 20 & 18 & 49 \\
\hline 6 & 10 & 15 & 5 & 45 \\
\hline 7 & 17 & 20 & 15 & 39 \\
\hline 8 & 8 & 16 & 17 & 40 \\
\hline 9 & 10 & 17 & 17 & 42 \\
\hline 10 & 11 & 9 & 18 & 43 \\
\hline 11 & 13 & 5 & 15 & 44 \\
\hline 12 & 16 & 11 & 14 & 30 \\
\hline 13 & 5 & 15 & 18 & 45 \\
\hline 14 & 11 & 15 & 15 & 45 \\
\hline 15 & 12 & 17 & 15 & 44 \\
\hline 16 & 15 & 20 & 16 & 43 \\
\hline 17 & 16 & 26 & 17 & 43 \\
\hline 18 & 15 & 30 & 14 & 44 \\
\hline 19 & 11 & 11 & 10 & 30 \\
\hline 20 & 10 & 10 & 11 & 30 \\
\hline
\end{tabular}




\section{Asaba Technical College, Asaba}

\begin{tabular}{|c|c|c|c|c|}
\hline & \multicolumn{2}{|c|}{ Control Group } & \multicolumn{2}{c|}{ Experimental Group } \\
\hline & Pre-test & Post-test & Pre-test & Post-test \\
\hline 1 & 5 & 22 & 16 & 50 \\
\hline 2 & 6 & 30 & 17 & 45 \\
\hline 3 & 10 & 21 & 26 & 40 \\
\hline 4 & 11 & 15 & 27 & 41 \\
\hline 5 & 12 & 14 & 18 & 42 \\
\hline 6 & 15 & 16 & 19 & 30 \\
\hline 7 & 5 & 17 & 15 & 33 \\
\hline 8 & 8 & 22 & 16 & 33 \\
\hline 9 & 10 & 27 & 17 & 40 \\
\hline 10 & 11 & 29 & 13 & 46 \\
\hline 11 & 12 & 21 & 15 & 47 \\
\hline 12 & 10 & 20 & 15 & 32 \\
\hline 13 & 10 & 20 & 14 & 31 \\
\hline 14 & 14 & 25 & 16 & 40 \\
\hline 15 & 15 & 25 & 17 & 36 \\
\hline 16 & 11 & 24 & 27 & 50 \\
\hline 17 & 12 & 16 & 30 & 49 \\
\hline 18 & 12 & 15 & 15 & 31 \\
\hline 19 & 13 & 30 & 16 & 34 \\
\hline 20 & 14 & 25 & 26 & 35 \\
\hline
\end{tabular}

\section{Ogor Technical College, Ughelli}

\begin{tabular}{|c|c|c|c|c|}
\hline & \multicolumn{2}{|c|}{ Control Group } & \multicolumn{2}{c|}{ Experimental Group } \\
\hline & Pre-test & Post-test & Pre-test & Post-test \\
\hline 1 & 8 & 20 & 5 & 30 \\
\hline 2 & 10 & 21 & 10 & 32 \\
\hline 3 & 11 & 14 & 9 & 42 \\
\hline 4 & 5 & 17 & 12 & 49 \\
\hline 5 & 6 & 18 & 13 & 23 \\
\hline 6 & 9 & 19 & 14 & 25 \\
\hline 7 & 11 & 20 & 15 & 26 \\
\hline 8 & 12 & 21 & 20 & 34 \\
\hline 9 & 14 & 25 & 21 & 35 \\
\hline 10 & 14 & 15 & 23 & 36 \\
\hline 11 & 12 & 16 & 14 & 30 \\
\hline 12 & 13 & 16 & 15 & 25 \\
\hline 13 & 15 & 16 & 16 & 26 \\
\hline 14 & 10 & 20 & 17 & 27 \\
\hline 15 & 11 & 21 & 18 & 28 \\
\hline 16 & 12 & 22 & 19 & 44 \\
\hline 17 & 12 & 10 & 22 & 46 \\
\hline 18 & 10 & 11 & 21 & 47 \\
\hline 19 & 10 & 12 & 14 & 30 \\
\hline 20 & 11 & 10 & 15 & \\
\hline
\end{tabular}




\section{Sapele Technical College, Sapele}

\begin{tabular}{|c|c|c|c|c|}
\hline & \multicolumn{2}{|c|}{ Control Group } & \multicolumn{2}{c|}{ Experimental Group } \\
\hline & Pre-test & Post-test & 10 & 40 \\
\hline 1 & 6 & 15 & 15 & 42 \\
\hline 2 & 8 & 16 & 17 & 46 \\
\hline 3 & 9 & 18 & 18 & 30 \\
\hline 4 & 11 & 17 & 10 & 35 \\
\hline 5 & 15 & 5 & 10 & 20 \\
\hline 6 & 8 & 10 & 16 & 25 \\
\hline 7 & 7 & 10 & 17 & 26 \\
\hline 8 & 8 & 10 & 18 & 44 \\
\hline 9 & 9 & 20 & 12 & 40 \\
\hline 10 & 10 & 12 & 10 & 41 \\
\hline 11 & 7 & 15 & 11 & 41 \\
\hline 12 & 10 & 11 & 12 & 41 \\
\hline 13 & 9 & 10 & 13 & 30 \\
\hline 14 & 11 & 12 & 12 & 35 \\
\hline 15 & 20 & 13 & 15 & 50 \\
\hline 16 & 12 & 13 & 16 & 36 \\
\hline 17 & 9 & 13 & 17 & 37 \\
\hline 18 & 8 & 12 & 10 & 40 \\
\hline 19 & 5 & 10 & 5 & \\
\hline 20 & 15 & 11 & & \\
\hline
\end{tabular}

\section{Analysis of the Data}

Unianova: Pretest by treatment with post-test

1 METHOD = STYPE $(3)$

1 INTERCEPT $=$ INCLUDE

1 PRINT = HOMOGENEITY DESCRIPTION

1 CRITERIA $=$ ALPHA (.05)

1 DESIGN $=$ POST TEST TREATMENT

Univariate Analysis of Variance (Data set 0)

Between - Subjects Factors

\begin{tabular}{|c|c|}
\hline & $\mathrm{N}$ \\
\hline Control $=1$ Expt. $=21.00$ & 99 \\
\hline 2.00 & 100 \\
\hline
\end{tabular}

\section{Descriptive Statistics}

Dependent variable pretest

\begin{tabular}{|c|c|c|c|}
\hline Control = 1 Expt. $=\mathbf{2}$ & Mean & Std. Deviation & N \\
\hline 1.00 & 11.6263 & 3.44812 & 99 \\
\hline 2.00 & 15.3700 & 4.44417 & 100 \\
\hline Total & 13.5075 & 4.39107 & 199 \\
\hline
\end{tabular}


Levene's Test of Equality of Error variances

Dependent Variable Pretest.

\begin{tabular}{|c|c|c|c|}
\hline F & df1 & df2 & Sig \\
\hline 1.817 & 1 & 1.97 & .179 \\
\hline
\end{tabular}

Tests the null hypothesis that the error variance of the dependent variable is equal across group

\section{a. Design Intercept Post-test treatment}

Test of Between-Subject Effect

Dependent Variable Pretest

\begin{tabular}{|l|c|c|c|c|c|}
\hline \multicolumn{1}{|c|}{ Source } & $\begin{array}{c}\text { Type III Sum of } \\
\text { Square }\end{array}$ & Df & Mean square & F & Sig \\
\hline Corrected model & 731.465 & 2 & 365.732 & 23.027 & .000 \\
\hline Intercept & 1496.854 & 1 & 1496.854 & 95.061 & .000 \\
\hline Posttest & 34.208 & 1 & 34.208 & 2.172 & .192 \\
\hline Treatment & 88.428 & 1 & 88.428 & 5.616 & .019 \\
\hline Error & 3086.274 & 196 & 15.786 & & \\
\hline Total & 40126.000 & 199 & & & \\
\hline Corrected Total & 3817.739 & 198 & & & \\
\hline
\end{tabular}

a. $\mathrm{R}$ squared $=.192$ Adjusted Required $=.183$

From the descriptive statistics table, it shows that control group is represented by 1.00 and the experimental group is represented by 2.00 meaning control group is pretest, which was represented by 1.00 and experimental group is represented by 2.00 which is post-test. From the table, the mean value of post-test of 15.3700 is $>$ than pre-test value of 11.6263. The standard deviation of post-test 4.44417 is also > than the pre-test value of 3.448121 . It therefore means that the post-test score is higher than pre-test score, showing there is a significant difference.

The null hypothesis shows that the error of variance of the dependent variable is equal across the two groups. The test between subjects of effects dependent variable of post-test, the value of F is 2.172. Since the F-value is > than the Pvalue, therefore the null hypothesis is rejected. The R-Squared of .192 is > than the adjusted R-squared showing that there is a great effect on the use of $3 \mathrm{D}$ animation for the teaching of the students.

\section{Findings of the Study}

The following findings were observed in the study:

- It was observed that students that used 3D computer animation did better in their study.

- Students that are taught with 3D computer animation understand the lesson better compared to when they are taught with lecture teaching method.

- The teaching of students with 3D computer animation has made teaching and learning to be simple, it removes the stress of not understanding what is being taught to them. 
- Students enjoy the teaching method, because 3D computer animation is self-explanatory. It involves practical methods, things that are taught are seen by the students.

- Students get the first-hand information during learning process because they see the components working.

- Teacher does less work of explanation students see components as they work thereby making students to understand what is being taught to them directly.

\section{RECOMMENDATIONS}

The following recommendations were made for this study:

- Students are motivated when they use 3D computer animation package to teach students in their learning process.

- $3 \mathrm{D}$ computer animation package has made the work of a teacher to be easy, because the 3D computer animation package shows the details of the lesson.

- $\quad$ Students learning with 3D computer animation package makes the learning be real.

- The teaching of students with 3D animation package makes when is being taught to them to be simple and interesting.

- The use of 3D computer animation package should be used to teach students because it makes learning and teaching to be motivating.

\section{CONCLUSIONS}

The use of $3 \mathrm{D}$ computer animation in the recent times, to teach students in this $21^{\text {st }}$ century will make teaching and learning of students to be interesting and motivating. It is made easy and simple because teaching is made real and understandable. When 3D animation is incorporated into the teaching of automobile in school system, students will be interested and motivated, because they will be seeing what they are taught visually.

\section{REFERENCES}

2. Auglin, G.J. et al., (1996). Visual Message Design and Learning: The role of static illustrations. Handbook of Research for Educational Communication and Technology. New York Macmillan Library Reference, USA.

3. Bellezza, F.S. (1996). A Mnemonic based on arranging words in a visual pattern. Journal of Educational Psychology, vol.78, Pp217-224.

4. Bhatti Z, et al., (2017). Be Educated: Multimedia learning through 3D Animation. International Journal of Computer Science and Emerging Technologies, vol. (1), pp.13-22.

5. Brooks, D.W. et al., (2001). Web-teaching: a guide for designing interactive teaching for the worldwide web. New York: Klumer Academic Plenum Publishers.

6. Cakiroglu U. \& Yilmaz, H. (2017). Using videos and 3D Animations for conceptual learning in Basic Computer units. Journal of Contemporary Educational Technology, vol.8 mo4, pp.390-405.

7. Gabriel, Amakievi Okien Ijeoma. "TRENDS IN THE IMPLEMENTATION OF NIGERIA'S NATIONAL POLICY ON TECHNICAL AND VOCATIONAL EDUCATION AND TRAINING: 1977-2014." International Journal of Humanities and Social Sciences (IJHSS) 7.3, Apr - May 2018; 71-88 
8. Hendajani, F. et al., (2008). 3D animation model with augmented reality for natural science learning in elementary schools. $4^{\text {th }}$ International Seminar of Mathematics, Science and Computer Science. Dio:10./088/1742-6596/10/2154.

9. KUMAR, D. SRINIVAS, and A. LAKSHUMU NAIDU. "THE BUSINESS PHILOSOPHIES FOR EXTENDED ENTERPRISE IN MANUFACTURING AUTOMOBILE SECTORS." International Journal of Mechanical and Production Engineering Research and Development (IJMPERD) 8.2, Apr 2018, 715-730

10. Keloe, C.M. (1996). Algorithms and Animation. On-line http://www.csgatech.edu/grade/k/colleeu.keloe/paper/litreview.html.

11. Mayer, R.E. (2001). Multimedia Learning. Cambridge University, United State of America.

12. Mayer, R.E. (2014). Cognitive Theory of Multimedia Learning. The Cambridge handbook of multimedia learning, pp43-71.

13. Liu, T.C., Liu Y.C. \& Kinshuk (2010). The Application of Simulating Assisted Learning Statistics (SALS) for correcting misconceptions and improving understanding of Computer Assisted Learning, 26, 143-158.

14. Mumtaz, S. (2002). Children's conception of Information Communications technology. Education and information technologies, 7(2), 155-168.

15. Pal, Shrabanti. "Evaluation of Financial Performance in Terms of Financial Ratios-An Empirical Study on Indian Automobile Industry." International Journal of Business Management \& Research 5.3 (2015): 1-7.

16. Papastergiou, M. (2005). Student Mental Models of the internet and their didactical exploitation in Informatics Education and Information Technologies, 10(4) 341-360.

17. Paliwal, Manisha, and ASHOK RASKAR. "Organisational Management in Pune's Auto Ancillaries." International Journal of Human Resource Management and Research (IJHRMR), ISSN (P) (2019): 2249-6874.

18. Rosenberg, M.L.. Statement for the Record on Unintentional Childhood Injury and Death. Assisted Secretary for Legislature (ASL) Department of Health and Human Service (online). Available: http://www.busgor.asttestify, t95050.html.

19. Wim, W.D. et al., (1991). Diagrams as aids to problem solving: their role in facilitating search and computation Educational Technology Research and Development vol.39, pp17-29.

20. Xiao, L. (2013). Animation Trend in Education. International Journal of Information and Education Technology, 3(3), 286289.

21. Zahra, S.B. (2011). Effect of Visual 3D Animation in Education. European Journal of Computer Science and Information Technology, vol.4 No.1, pp1-9. 

